\title{
Escherichia fergusonii identified in preputial swabs from healthy Aceh cattle by phylogenetic 16S rRNA analysis
}

\section{Ummu Balqis' ${ }^{1}$, Muhammad Hambal' ${ }^{1}$, Masda Admi ${ }^{1,2}$, Safika ${ }^{3}$, Nellita Meutia ${ }^{4}$, Sugito ${ }^{1}$, Dasrul ${ }^{1}$, Mohd. Agus Nashri Abdullah ${ }^{5}$, T. Reza Ferasyi ${ }^{1}$, Triva Murtina Lubis ${ }^{1}$, Mahdi Abrar $^{1}$ and Darmawi ${ }^{1 *}$}

${ }^{1}$ Faculty of Veterinary Medicine, Syiah Kuala University, Jl. Tgk. H. Hasan Krueng Kalee No. 4 Darussalam-Banda Aceh, 23111, Indonesia.

${ }^{2}$ Postgraduate Student of Mathematics and Applied Sciences, Syiah Kuala University, Darussalam-Banda Aceh, 23111, Indonesia.

${ }^{3}$ Faculty of Veterinary Medicine, Bogor Agricultural University, Jl. Agatis Dramaga-Bogor, 16680, Indonesia. ${ }^{4}$ Indrapuri Breeding and Forage Center of Aceh Cattle, Indrapuri District, Banda Aceh, Indonesia. ${ }^{5}$ Faculty of Agriculture, Syiah Kuala University, Banda Aceh, Indonesia.

Email: darmawi@unsyiah.ac.id

Received 30 May 2017; Received in revised form 19 September 2017; Accepted 11 April 2018

\begin{abstract}
Aims: This study aimed to assess the risk of reproductive tract contamination in Aceh cattle by Escherichia fergusonii as revealed by $16 \mathrm{~S}$ rRNA gene sequencing of preputial swab samples.

Methodology and results: Preputial swabs taken from 50 breeding bulls at the Indrapuri Breeding and Forage Center of Aceh Cattle, Banda Aceh, Indonesia, were examined for the presence of bacteria. Samples were streaked on MacConkey agar and incubated under aerobic conditions at $37{ }^{\circ} \mathrm{C}$ for $24 \mathrm{~h}$. Smooth, yellow- or rose-colored colonies were selected for their characteristic appearance and subjected to further analysis. Genetic identification was based on 16S rRNA gene sequencing and PCR analysis. We conducted a 16S rRNA sequence similarity search with GenBank using BLAST and constructed neighbour-joining dendrograms using MEGA. From among closely related species of the genus Enterobacteriaceae, we identified the enteric bacterium $E$. fergusonii as having the highest sequence similarity. Conclusion, significance and impact of study: We concluded that the $E$. fergusonii bacterium positively presence in preputial swab samples of clinically healthy Aceh cattle population. Accordingly, it is potentially allowing the bacterium to be spread during natural mating or semen collection processing for artificial insemination in cattle breeding farm.
\end{abstract}

Keywords: Aceh cattle, Escherichia fergusonii, 16S rRNA gene, sequencing

\section{INTRODUCTION}

Aceh cattle are one of the most important domestic cattle breeds in Indonesia, and they occupy an economically prominent position in the livestock industry of many regions. In rural areas, Aceh cattle not only provide meat and milk but also are a principal animal for draft work. Thus, attention must be focused on animal pathogencaused diseases to ensure that a sufficient supply of Aceh cattle and their products are available. Ultimately, improvement of cattle reproduction may be expected to significantly increase the economy and living standards of many rural communities throughout the world.

Accordingly, we focused our research on pathogenic bacteria that pose a potential risk to animal health by causing widespread disease, particularly in cattle breeding farms. As contagious diseases may affect the reproductive performance of cattle, microbial preputial infections have been a major concern for cattle breeders.
The preputial bacterial load plays a critical role in the transfer of serious disease during the breeding season because this form of transmission may act as a vehicle for a broad range of undesirable pathogens. Bacterial contamination of the preputial orifice by extraneous flora and true pathogens directly from soil, bedding and manure may occur routinely. In support of this hypothesis, several authors have suggested that there may be multiple potential sources for preputial infection owing to the ubiquitous nature of the contributory bacteria (Joshi et al., 2006; Silva et al., 2013; Meena et al., 2015; Rahmi et al., 2015).

The preputial orifice of animals is likely a major source of diverse bacterial species that lead to disease and the risk of microbial spread during the collection of semen destined for use in artificial insemination. Numerous bacterial agents have been isolated worldwide from semen specimens of cattle and other domestic animals. Recently, bacterial organisms such as Micrococcus 
luteus, Pseudomonas aeruginosa, S. epidermidis and Staphylococcus intermedius have been detected in frozen bovine semen (Abro et al., 2016). Sannat et al. (2015) described bacterial loads found in fresh and frozen semen from different breeds of cattle and buffalo. In Iranian bovine and buffalo semen, Dehkordi et al. (2014) identified Brucella abortus and Brucella melitensis, which are highly contagious zoonotic pathogens of humans and the leading pathogenic bacterial causes of abortion in ruminants. Azawi and Ismaeel (2012) detected aerobic bacteria in Awassi ram semen. Rana et al. (2012) assessed the bacterial diversity in fresh bubaline semen and isolated Micrococcus spp., Bacillus spp., Rhodococcus equi, Stapyhococcus auricularis, Moraxella bovis, S. chromogenes, S. simulans and Enterobacter spp. Patel and Patel (2012) found both Gram-positive and Gram-negative bacteria in the frozen semen of Holstein cattle bulls. Gandhi et al. (2008) isolated the Gramnegative bacterium Moraxella bovis, an opportunistic pathogen that can cause infectious bovine keratoconjunctivitis, from frozen bovine semen of clinically healthy Jersey and Jersey-cross bulls.

Escherichia fergusonii, a member of Enterobacteriaceae, is globally distributed and associated with a wide variety of intestinal and extra-intestinal infections in both humans and animals. For example, in a case study from Switzerland, Funke et al. (1993) reported the potential pathogenicity of $E$. fergusonii after they isolated the strain from the feces, gallbladder fluid and a superficial wound of a 69-year-old male patient with pancreatic carcinoma and cholangiosepsis. In a study of patients at an Italian hospital, Savini et al. (2009) described $E$. fergusonii as contributing to the bacterial commensal flora of the human enteric tract. Isolates of $E$. fergusonii were also obtained from farm animals in the United Kingdom (Wragg et al., 2009) and from swine and poultry in South Korea (Rayamajhi et al., 2011). More recently, in Egypt, Gaafar et al. (2015) found E. fergusoni to be an emerging bacterial pathogen of freshwater fish and the probable cause of a fatal disease outbreak in Nile tilapia (Oreochromis niloticus).

Several investigators have specifically referred to $E$. fergusonii as a potential emerging pathogen. Herràez et al. (2005) reported that $E$. fergusonii infection caused fatal fibrinonecrotic typhlitis in two ostrich specimens (Struthio camelus) that had developed clinical signs of hemorrhagic diarrhea, prostration and anorexia. In another case in Canada, a goat developed chronic diarrhea and became emaciated, and E. fergusonii was isolated from the feces and several internal organs, namely, kidney, lung, liver and intestine (Hariharan et al. (2007). Recently, in an investigation of non-human primates in Africa, Glover et al. (2017) identified E. fergusonii as a possible emerging pathogen of zoonotic importance.

In sum, E. fergusonii has been found in many environments, including the aquatic milieu (Maheux et al., 2014), that may potentially allow the bacterium to spread; in this context, E. fergusonii poses a substantial risk to veterinary health in cattle breeding farms. For example, a case of $E$. fergusonii infection in a pregnant cow was associated with clinical signs of acute pneumonia, hyperthermia, tachypnea and eventual death (Rimoldi and Moeller Jr., 2013). To avoid contagion, careful evaluation of reproductive tract infection-particularly in the preputial area-is indicated. Therefore, our present investigation was designed to analyze preputial swab samples from clinically healthy Aceh cattle for the presence of $E$. fergusonii. Furthermore, we used genotypic characterization of the bacterial 16S rRNA gene by polymerase chain reaction (PCR) amplification and subsequent phylogenetic analysis to elucidate the taxonomic position of E. fergusonii in the Escherichiaceae group.

\section{MATERIALS AND METHODS}

\section{Specimen collection}

Preputial swab samples were obtained under sterile hygienic conditions from 50 healthy Aceh bulls, two to three years of age, maintained at the local breeding center, the Indrapuri Breeding and Forage Center of Aceh Cattle, Indrapuri District, Banda Aceh, Indonesia. The external genitalia of male Aceh cattle were cleaned with sterile gauze moistened with $0.9 \%$ sodium chloride. Preputial secretions were collected on sterile cotton swabs, transferred to sterile tubes and kept in boxes at an isothermal temperature of $8{ }^{\circ} \mathrm{C}$ and transported to the Laboratory of Research, Faculty of Veterinary Medicine of Syiah Kuala University.

\section{Isolation of preputial bacterium}

Samples from preputial swabs were streaked on Petri dishes that contained MacConkey agar (Difco Laboratories, Detroit, MI, USA) and incubated under aerobic conditions at $37{ }^{\circ} \mathrm{C}$ for $24 \mathrm{~h}$. Bacteria were isolated and identified as described (Silva et al., 2013). Characteristic smooth, yellow- and rose-colored colonies were selected for further identification. Colonies were restreaked on the same medium to obtain pure cultures. Isolated colonies were identified morphologically by Gram staining (Chai et al., 2017) and by biochemical tests (Bakar et al., 2017). Indole production, methyl red, Voges Proskauer, citrate, sulfic indole motility, mannitol, triple sugar iron agar, sucrose, and glugose tests were carried out.

\section{DNA extraction}

Total DNA was extracted separately using the gDNA PrestoTM Bacteria Mini kit (Geneaid) with slight modification. Purified total DNA $(50 \mu \mathrm{L}, \sim 200 \mu \mathrm{g} / \mathrm{mL})$ was eluted and used as the template for PCR assays as described by Sari et al. (2017).

\section{Amplification of the 16S rRNA gene via PCR}

The bacteria-specific primers for the 16S rRNA gene (Baker et al., 2003) used for detecting the preputial 
bacteria in the Aceh cattle population were as follows: forward: 5'-AGAGTTTGATC(A/C)TGGCTCAG-3'; reverse: 5'-GGTTAC(G/C)TTGTTACCTGCCGGA-3'. Expected amplicon size was 1500 bp. 16S rRNA was amplified through PCR: Each reaction mixture (25 $\mu \mathrm{L}$ total) contained $10 \mathrm{pmol}$ of each primer, $30 \mathrm{ng}$ of template DNA and $12.5 \mu \mathrm{L}$ of Master mix (KAPA Biosystems, Boston, MA, USA). The PCR amplification program was as follows: initial denaturation at $95^{\circ} \mathrm{C}, 5 \mathrm{~min}$, followed by 30 cycles consisting of denaturation at $95{ }^{\circ} \mathrm{C}, 1 \mathrm{~min}$, annealing at $50{ }^{\circ} \mathrm{C}, 30 \mathrm{sec}$, and elongation at $72{ }^{\circ} \mathrm{C}, 2$ min, with a final extension at $72{ }^{\circ} \mathrm{C}, 10 \mathrm{~min}$. The PCR product was identified by electrophoresis through $1.0 \%$ agarose in $1 \times$ TAE buffer $(40 \mathrm{mM}$ Tris- $\mathrm{HCl}, 40 \mathrm{mM}$ acetate, $1.0 \mathrm{mM}$ EDTA, pH 8.3) and analysis with the Gel Doc XR+ System (Bio-Rad).

\section{Identification of the bacterium by 16S rRNA gene sequencing}

Genetic identification was based on 16S rRNA gene sequencing and PCR analysis. The 16S rRNA analysis was performed on nine isolates from Banda Aceh bulls by sequencing $>1400$ nucleotides of the 16S rRNA gene. DNA was extracted with a Presto ${ }^{\mathrm{TM}}$ Mini gDNA Bacteria kit (Geneaid) and amplified using the universal primers BacF: 5'-TTTTACTGTTTTCGTAACAGTTTT-3', and UniB: 5'ACGCCACCGAGC-3', $\pm 1500 \mathrm{bp}$. This process amplified $16 S$ rRNA gene that have length about 1500 bp. Cycle sequencing was performed with the KAPA 2G Fast ReadyMix PCR kit with dye and reaction products were sequenced by Macrogen Inc., Korea, using the Dye Terminator (3'-dye labeled dideoxynucleotide triphosphate). The amplified products were checked for purity and size by $1.2 \%(\mathrm{w} / \mathrm{v})$ agarose gel electrophoresis in TAE buffer ( $\mathrm{pH}$ 8.3). The 16S rRNA gene sequences determined in this study were aligned with sequences from GenBank using the CrustalW program in MEGA version 5.0. The multiple sequence alignment was edited by hand and used to derive a neighbor-joining tree with 1000 bootstraps (Castro et al., 2010; Mitra and Roy, 2010; Sujatha et al., 2012; Ntushelo, 2013; Sari et al., 2017).

\section{Phylogenetic analysis}

The sequencing results were compared using the Basic Local Alignment Search Tool (BLAST) program from NCBI (http://www.ncbi.nlm.nih.gov) and 16S rRNA gene sequence homology analysis using GenBank data. A phylogenetic tree was constructed using distance matrices by the neighbor-joining model of the MEGA 6.1 program (Tamura et al., 2011) with the substitution method Maximum Composite Likelihood (Tamura and Nei, 1993). The node reproducibility for tree topology was estimated by bootstrap analysis with 1000 replicate datasets. A Bacillus sp. was included as an outgroup for phylogenetic analysis.

\section{RESULTS}

Of 50 bovine preputial specimens analyzed, 9 (18\%) yielded bacterial isolates. The bacterium formed smooth, yellow- and rose-colored colonies that were raised and irregularly shaped. Morphologically, the oval bacterium was classified as a Gram-negative rod based on Gram staining. The biochemical reactions of the bacterium are listed in Table 1. Homology analysis (Table 2) revealed that most isolated sequences were closely related to $E$. fergusonii strain ATCC 35469 with 99\% identity to the sequences of the Enterobacteriaceae group available in GenBank. Based on the results of the phylogenetic tree, $E$. fergusonii was identified as the nearest phylogenetic relative of the bacterium, and we found that a small number of sequences formed a new cluster. The bacterium isolate, $8 \mathrm{a}$, showed the highest similarities with five other enteric bacteria, namely, Enterobacter massiliensis, Citrobacter youngae strain, Escherichia albertii strain Albert, Shigella fexnerii and Shigella boydii. Comparative 16S rRNA gene sequence analysis demonstrated that the bacterium was a member of an RNA group affiliated with the Enterobacteriaceae group. The bacterium was $99 \%$ similar to the Enterobacteriaceae group as shown in the phylogenetic tree in Figure 1.

Table 1: Biochemical reactions of $E$. fergusonii isolated from preputial swabs of Aceh cattle.

\begin{tabular}{lll}
\hline No. & Test & Reaction \\
\hline 1 & Indole production & + \\
2 & Methyl red & + \\
3 & Voges Proskauer & - \\
4 & Citrate (Simmons) & - \\
5 & Sulfic indole motility & - \\
6 & Mannitol & - \\
7 & Triple sugar iron agar & Acid/gas \\
8 & Sucrose & - \\
9 & Glucose & - \\
\hline
\end{tabular}

\section{DISCUSSION}

The bacterial load in animal reproductive organs is unique, and its complexity may be increased by preputial or vaginal bacteria that may ultimately determine overall animal health. It is therefore advisable to investigate these bacteria to understand the underlying causes of reproductive organ disorders. Each animal appears to harbor a unique bacterial community (Silva et al., 2013; Meena et al., 2015). For example, C. fetus, C. fetus subsp. venerealis, and $C$. fetus subsp. fetus were isolated from prepuces of buffalo bulls (Joshi et al., 2006). Silva et al. (2013) identified Staphylococcus intermedius and Proteus mirabilis, which are aerobic bacterial microbiota that have been most frequently isolated from preputial and vaginal specimens of owl monkeys (Aotus azarai infulatus). 
Table 2: List of the sequences that showed similarity with the Enterobacteriaceae group.

\begin{tabular}{|c|c|c|c|}
\hline Source of $16 \mathrm{~S}$ ribosomal RNA gene & Strain & Accession Number & Sequence \\
\hline Escherichia fergusonii & ATCC 35469 & NR 074902.1 & complete \\
\hline Escherichia fergusonii & NBRC 102419 & NR 114079.1 & partial \\
\hline Enterobacter massiliensis & JC163 & NR 125600.1 & partial \\
\hline Citrobacter youngae & GTC 1314 & NR 041527.1 & partial \\
\hline Escherichia fergusonii & ATCC 35469 & NR 027549.1 & partial \\
\hline Escherichia albertii & Albert 19982 & NR 025569.1 & partial \\
\hline Shigella flexneri & ATCC 29903 & NR 026331.1 & partial \\
\hline Escherichia coli & U $5 / 41$ & NR 024570.1 & partial \\
\hline
\end{tabular}

Values for the following parameters are identical for all sequences: Max Score and Total Score: 754; Query cover: 99\%; E value: 0.0; Identity: $99 \%$.

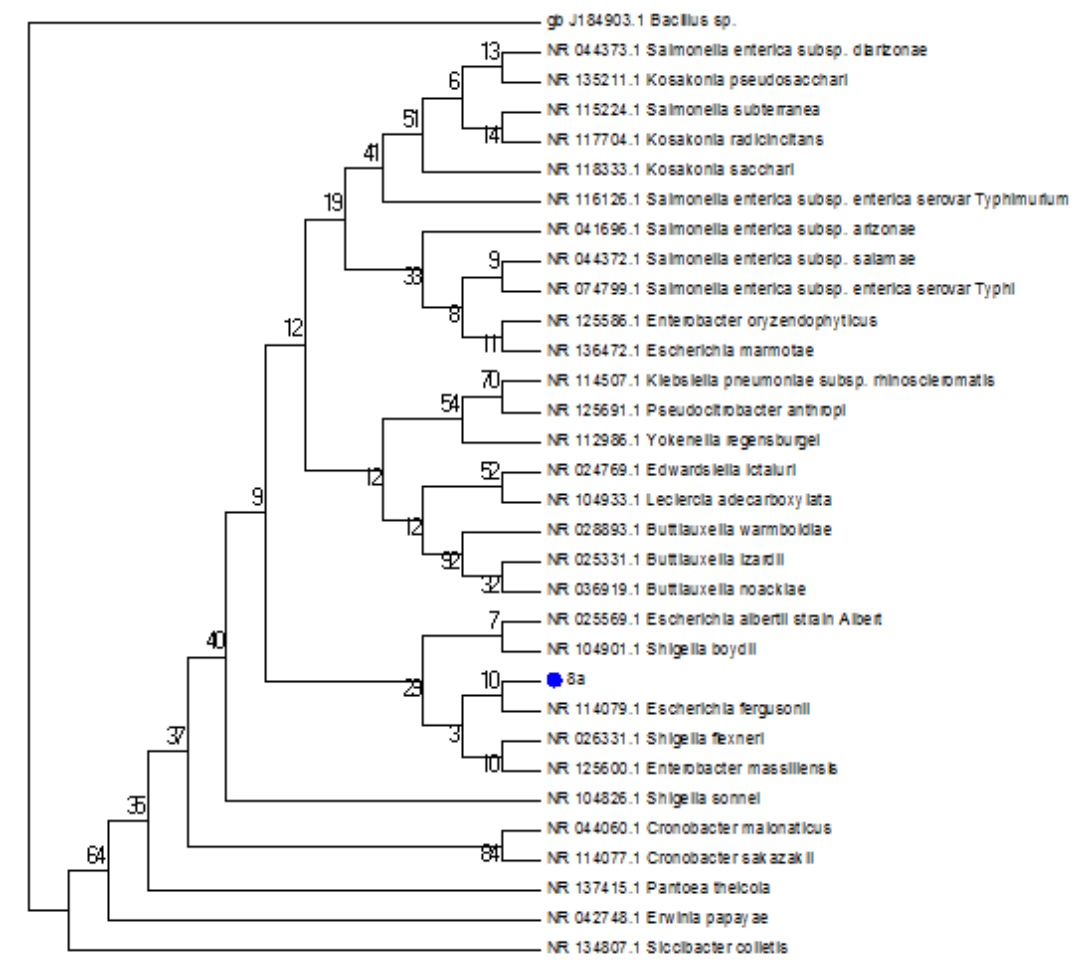

Figure 1: Phylogenetic tree of enteric bacteria constructed using the 16S rRNA gene.

Furthermore, Staphylococcus aureus was detected by Rahmi et al. (2015) in the prepuces and vaginas of horses (Equus caballus). Indeed, preputial washing reduces the presence of the bacterial load in the ejaculates of Murrah buffalo bulls (Meena et al., 2015).

Although $E$. fergusonii is considered a part of bacterial commensal flora in the enteric tract, the bacterium may colonize other organs to became virulent when conditions become conducive for growth and multiplication, which supports its role as an opportunistic pathogenic bacterium. Indeed, it is well known from veterinary reports that, under immunosuppressive conditions, transient microorganisms or resident microbiota that originated from the digestive tract may cause disease in the reproductive tract. For example, many commensal microorganisms are known to infect the reproductive tract and cause conditions like epididymitis, prostatitis, seminal vesiculitis, testicular degeneration, urethral inflammation, ampulitis, posthitis, orchitis and balanitis (Monleon et al., 2008; Lisboa et al., 2009; Rajiah et al., 2012; Altarac, 2015; Delcaru et al., 2016). Notably, these maladies often affect the prepuce and may result in male infertility.

In particular, E. fergusonii may act as pathogens under certain circumstances, and they are cited as responsible for several emerging bacterial diseases in animals and humans (Funke et al., 1993; Savini et al., 2009). We describe herein that the preputial colonization 
of cattle by potential emerging opportunistic veterinaryand human-pathogenic bacteria such as $E$. fergusonii may result in the contamination from the environment. This phenomenon can cause serious and even fatal infections in otherwise healthy hosts. Rimoldi and Moeller Jr. (2013) described that $E$. fergusonii may function as a fatal pulmonary pathogen and cause acute pneumonia, leading to death in cattle. Previously, Weiss et al. (2011) observed a similar phenomenon in the horse with $E$. fergusonii possibly emerging as an opportunistic pathogen that caused enteritis and septicemia. In the chicken, Oh et al. (2012) found that E. fergusonii produced heat-labile enterotoxin. Moreover, Gokhale et al. (2014) reported that E. fergusonii caused a chronic low-grade endophthalmitis after cataract surgery. In the aquatic environment, Gaafar et al. (2015) reported that $E$. fergusonii caused pathological lesions, mortality and morbidity in tilapia.

Infection with $E$. fergusonii increases not only the risk of disease but also the associated phenomenon of increased resistance to antibiotics both in humans and animals. Lagacé-Wiens et al. (2010) isolated E. fergusonii from urine samples of a patient with cystitis, and their analyses demonstrated a high level of bacterial multidrug resistance to cephalosporins, fluoroquinolones, sulfonamides, monobactams and aminopenicillins. This result was similar to previous findings by Savini et al. (2008) of multidrug resistance of $E$. fergusonii recovered from a patient with clinical signs of acute cystitis. Ramayajhi et al. (2011) described the prevalence of $\beta$ lactam resistance of $E$. fergusonii in swine and poultry. Multidrug-resistant and virulent E. fergusonii were also detected by Forgetta et al. (2012), who demonstrated the presence of antibiotic resistance genes in chromosomes and plasmids of $E$. fergusonii isolated from broiler chickens. In light of the available data, we argue that the resistance of $E$. fergusonii to multiple classes of antibiotics has undoubtedly resulted in treatment failures and prolonged illnesses and a higher risk of invasive disease.

Various bacteria have now been recognized as important emerging pathogens in the reproductive tract, and several have been demonstrated to cause disease in both humans (Lisboa et al., 2009; Rajiah et al., 2012; Altarac, 2015; Delcaru et al., 2016) and animals (Monleon et al., 2008; Oh et al., 2012; Rana et al., 2012). In humans, various types of infections related to balanitis and infectious balanoposthitis have been reported in circumcised or uncircumcised males (Lisboa et al., 2009; Rajiah et al., 2012). Escherichia coli is able to adhere to and colonize the perineum and urethra and cause urinary tract infections (Altarac, 2015). Delcaru et al. (2016) described that bacterial biofilm formation, which is commonly caused by Gram-negative bacteria, can lead to urinary tract infection and prostatitis syndromes. In animals, Monleon et al. (2008) found that both Staphylococcus aureus and $E$. coli have been implicated as causes of orchitis and epididymo-orchitis in poultry broiler breeders. Enterobacter spp., a recognized cause of coliform mastitis in neonatal and calf diarrhea, was recovered by Rana et al. (2012) in fresh bubaline semen.
An increasing preputial bacterial load leads to contamination that affects semen quality as manifested by toxic effects on spermatozoa. Bacteriospermia in semen can lead to changes in the integrity and viability of spermatozoa and affect fertilization by direct adherence of the bacteria to individual sperm cells. Bacteria may also have indirect effects in semen. For example, Morrell (2006) described that toxins released by bacteria can impair spermatozoa motility. Thus, preputial hygiene is a primary consideration in the prevention of pathogenic bacterial transmission through artificial insemination or natural mating conditions. Because the majority of bacteria present in semen come from the prepuce, Joshi et al. (2006) advised that, during semen-collecting procedures, bull preputial cavities be systematically cleaned.

\section{ACKNOWLEDGEMENTS}

We wish to thank the technical staff of the Research Laboratory Faculty of Veterinary Medicine for their assistance. We also thank Mr. S. F. Santosa for expert technical help in preparation of materials. We are thankful to the Research and Community Service of Syiah Kuala University for funding of the grant awarded by the Hibah Penelitian Unggulan Unsyiah (No. 76/UN11.2/PP/PNBP/SP3/2017).

\section{REFERENCES}

Abro, S. H., Abro, R., Rind, R., Kamboh, A. A., Memon, A. A., Channa, A. A., Wagan, H., Baloch, H. and Wagan, B. (2016). Antibiogram of the Micrococcus luteus, Pseudomonas aeruginosa, Staphylococcus epidermidis and Staphylococcus intermedius isolated from the bovine frozen semen. Pure and Applied Biology 5, 204-212.

Altarac, S. (2015). Urinary tract infection: How it happens? European Medical Journal 3, 62-67.

Azawi, O. I. and Ismaeel, M. A. (2012). Effects of seasons on some semen parameters and bacterial contamination of Awassi ram semen. Reproduction in Domestic Animals 47, 403-406.

Bakar, N. A. A., Rahman, M. H. A. and Shakri, N. A. (2017). Identification and characterization of lactic acid bacteria isolated from fruit tree rhizosphere in MARDI, Malaysia. Malaysian Journal of Microbiology 13, 6166.

Baker, G. C., Smith, J. J. and Cowan, D. A. (2003). Review and re-analysis of domain-specific $16 \mathrm{~S}$ primers. Journal of Microbiological Methods 55, 541555.

Castro, C. E. F., Knezetic, J. A. and Cavalieri, S. J. (2010). Use of 16s rRNA gene sequencing to identify a case of Pediococcus parvulus bacteremia in a patient with metastatic testicular cancer. Laboratory Medicine 41, 93-95.

Chai, W. T., Gansau, J. A., Atong, M., Kadir, J., Poili, E. and Chong, K. P. (2017). First report of Erwinia psidii 
associated with papaya dieback disease in Malaysia. Malaysian Journal of Microbiology 13, 20-25.

Dehkordi, F. S., Khamesipour, F. and Momeni, M. (2014). Brucella abortus and Brucella melitensis in Iranian bovine and buffalo semen samples: The first clinical trial on seasonal, senile and geographical distribution using culture, conventional and real-time polymerase chain reaction assays. Kafkas Universitesi Veteriner Fakultesi Dergisi 20, 821-828.

Delcaru, C., Alexandru, I., Podgoreanu, P. and Grosu, M. (2016). Microbial biofilms in urinary tract infections and prostatitis: Etiology, pathogenicity, and combating strategies. Pathogens 5, 65.

Forgetta, V., Rempel, H., Malouin, F., Vaillancourt, R. Jr., Topp, E., Dewar, K. and Diarra, M. S. (2012). Pathogenic and multidrug-resistant Escherichia fergusonii from broiler chicken. Poultry Science 91, 512-525.

Funke, G., Hany, A. and Altwegg, M. (1993). Isolation of Escherichia fergusonii from four different sites in a patient with pancreatic carcinoma and cholangiosepsis. Journal of Clinical Microbiology 31, 2201-2203.

Gaafar, A. Y., Younes, A. M., Kenawy, A. M., Soliman, W. S. and Mohamed, L. A. (2015). Escherichia fergusonii: A new emerging bacterial disease of farmed nile tilapia (Oreochromis niloticus). Global Veterinaria 14, 268-273.

Gandhi, A., Sharma, M., Dhar, P., Katoch, V., Thakur, A. and Kumar, R. (2008). Isolation of Moraxella bovis from frozen bovine semen and determination of microbial load. Indian Journal of Microbiology 48, 405407.

Glover, B., Wentzel, J., Jenkins, A. and Vuuren, M. V. (2017). The first report of Escherichia fergusonii isolated from non-human primates, in Africa. One Health 3, 70-75.

Gokhale, V. V., Therese, K. L., Bagyalakshmi, R. and Biswas, J. (2014). Detection of Escherichia fergusonii by PCR-based DNA sequencing in a case of delayed-onset chronic endophthalmitis after cataract surgery. Journal of Cataract \& Refractive Surgery 40, 327-330.

Hariharan, H., Lopez, A., Conboy, G., Coles, M. and Muirhead, T. (2007). Isolation of Escherichia fergusonii from the feces and internal organs of a goat with diarrhea. Canadian Veterinary Journal 48, 630631.

Herràez, P., Rodriguez, F., Espinosa de los Monteros, A., Acosta, B., Jaber, J. R., Castellano, J. and Castro, A. (2005). Fibrino-necrotic typhlitis caused by Escherichia fergusonii in ostriches (Struthio camelus). Avian Disease 49, 167-169.

Joshi, K., Sharma, N. S., Jand, S. K. and Oberoi, M. S. (2006). Prevalence of Campylobacter fetus in cattle and buffalo breeding bulls in northern India. Indian Journal of Animal Sciences 76, 609-611.

Lagacé-Wiens, P. R., Baudry, P. J., Pang, P. and Hammond, G. (2010). First description of an extended-spectrum-ß-lactamase producing multidrug- resistant Escherichia fergusonii strain in a patient with cystitis. Journal of Clinical Microbiology 48, 23012302.

Lisboa, M. D. C., Ferreira, M. D. A., Resende, M. D. C. and Rodrigues, A. G. (2009). Infectious balanoposthitis: management, clinical and laboratory features. International Journal of Dermatology 48, 121124.

Maheux, A. F., Boudreau, D. K., Bergeron, M. G. and Rodriguez, M. J. (2014). Characterization of Escherichia fergusonii and Escherichia albertii isolated from water. Journal of Applied Microbiology 117, 597-609.

Meena, G. S., Raina, V. S., Gupta, A. K., Mohanty, T. K., Bhakat, M., Abdullah, M. and Bishist, R. (2015). Effect of preputial washing on bacterial load and preservability of semen in murrah buffalo bulls. Veterinary World 8, 798-803.

Mitra, S. and Roy, P. (2010). Molecular indentification by $16 S$ rDNA sequence of a novel bacterium capable of degrading trychloroethylene. Journal of Biological Sciences 10, 637-642.

Monleon, R., Martin, M. P. and Barnes, H. J. (2008). Bacterial orchitis and epididymo-orchitis in broiler breeders, Avian Pathology 37, 613-617.

Morrell, J. M. (2006). Update on semen technologies for animal breeding. Reproduction in Domestic Animals 41, 63-67.

Ntushelo, K. (2013). Identifying bacteria and studying bacterial diversity using the $16 \mathrm{~S}$ ribosomal RNA genebased sequencing techniques: a review. African Journal of Microbiology Research 7, 5533-5540.

Oh, J. Y., Kang, M. S., An, B. K., Shin, E. G., Kim, M. J., Kwon, J. H. and Kwon, Y. K. (2012). Isolation and epidemiological characterization of heat-labile enterotoxin-producing Escherichia fergusonii from healthy chickens. Veterinary Microbiology 160, 170175.

Patel, D. Y. and Patel, R. K. (2012). Estimation of biochemical activities of microbial load isolated from the frozen semen of HF and HF crossbred cattle bulls. Current Trends in Biotechnology and Pharmacy 6, 328-339.

Rahmi, Y., Darmawi, Abrar, M., Jamin, F., Fakhrurrazi and Fahrimal, Y. (2015). Identification of Staphylococcus aureus in preputium and vagina of horses (Equus caballus). Journal Medica Veterinaria 9, 154-158.

Rajiah, K., Veettil, S. K., Kumar, S. and Mathew, E. M. (2012). Study on various types of infections related to balanitis in circumcised or uncircumcised male and its causes. African Journal of Pharmacy and Pharmacology 6, 74-83.

Rana, N., Vaid, R. K., Phulia, S. K. and Singh, P. (2012). Assessment of bacterial diversity in fresh bubaline semen. Indian Journal of Animal Sciences 82, 596-598.

Rayamajhi, N., Cha, S. B., Shin, S. W., Jung, B. Y., Lim, S. K. and Yoo, H. S. (2011). Plasmid typing and resistance profiling of Escherichia fergusonii and other 
Enterobacteriaceae isolates from South Korean farm animals. Applied and Environmental Microbiology 77, 3163-3166.

Rimoldi, G. M. and Moeller Jr. R. B. (2013). Escherichia fergusonii associated with pneumonia in a beef cow. Journal of Veterinary Medicine 1, 1-3.

Sannat, C., Nair, A., Sahu, S. B., Sahasrabudhe, S. A., Kumar, A., Gupta, A. K. and Shende, R. K. (2015). Effect of species, breed and age on bacterial load in bovine and bubaline semen. Veterinary World 8, 461466.

Sari, W. N., Safika, Darmawi, and Fahrimal, Y. (2017). Isolation and identification of a cellulolytic Enterobacter from rumen of Aceh cattle. Veterinary World 10, 15151520.

Savini, V., Catavitello, C., Bianco, A., Masciarelli, G., Astolfi, D., Balbinot, A. and D'Antonio, D. (2009). First enteric Escherichia fergusonii from Italy. Le Infezioni in Medicina 4, 259-260.

Savini, V., Catavitello, C., Talia, M., Manna, A., Pompetti, F., Favaro, M., Fontana, C., Febbo, F., Balbinot, A., Berardino, F. D., Bonaventura, G. D., Zacomo, S. D., Esattore, F. and D'Antonio, D. (2008). Multidrug-Resistant Escherichia fergusonii: A Case of Acute Cystitis. Journal of Clinical Microbiology 46, 1551-1552.

Silva, G. A. da., Monteiro, F. O. B., Dias, H. L. T., Cavalcante, R. de O., Sampaio, A. I. da F., da Conceicao, M. E. B. A. M., Takeshita, R. S. C., de Castro, P. H. G., Feijo, F. M. C. and Rahal, S. C. (2013). Qualitative analysis of preputial and vaginal bacterial microbiota in owl monkeys (Aotus azarai infulatus) raised in captivity. Journal of Medical Primatology 42, 71-78.

Sujatha, P., Kumar, B. N. and Kalarani, V. (2012). Isolation, characterization, and molecular identification of bacteria from tannery effluent using $16 \mathrm{~S}$ rRNA sequencing. Current Biotica 16, 198-207.

Tamura, K. and Nei, M. (1993). Estimation of the number of nucleotide substitutions in the control region of mitochondrial DNA in humans and chimpanzees. Molecular Biology and Evolution 10, 512-526.

Tamura, K., Peterson, D., Peterson, N., Stecher, G., Nei, M. and Kumar, S. (2011). MEGA 5: Molecular evolutionary genetics analysis using maximum likelihood, evolutionary distance, and maximum parsimony methods. Molecular Biology and Evolution 28, 2731-2739.

Weiss, A. T. A., Lubke-Becker, A., Krenz, M. and van der Grinten, E. (2011). Enteritis and septicemia in a horse associated with infection by Escherichia fergusonii. Journal of Equine Veterinary Science, 31, 361-364.

Wragg, P., Ragione L. R. M., Best, A., Reichel, R., Anjum, M. F., Mafura, M. and Woodward, M. J. (2009). Characterisation of Escherichia fergusonii isolates from farm animals using an Escherichia coli virulence gene array and tissue culture adherence assays. Research in Veterinary Science 86, 27-35. 